\title{
A KOLOZSVÁRI EGYETEM 1872-1919 KÖZÖTTI TÖRTÉNETE, LEVÉLTÁRI ÉS KÖNYVTÁRI DOKUMENTUMAINAK FELTÁRÁSA ÉS DIGITALIZÁLÁSA
}

\begin{abstract}
THE History of the University of KolozsVÁ IN the Years 1872 to 1919: THE EXploration and the Digitalization of ITS ARCHIVAL MATERIAL and LibRaRY Documents. The research program discussed here was launched by the Archives of the University of Szeged in the spring of 2014, and its major objective has been the exploration of archival material and library documents from the various collections to be found in Kolozsvár, Marosvásárhely and Hungary. Additional aims include the actual digitalization of documents, making the digitalized stock available primarily for university students and for the teaching staff, as well as the promotion of historical research. The head of the program provides here a detailed account of the project's justifications, preparation, the hitherto covered stages, the execution of source collection and digital photography, as well as the program's infrastructural and personal demands. Mention is also made of making the project results available, as well as the possibilities of utilization. The tasks of the near future are also treated.
\end{abstract}

\section{Bevezetés}

Az 1872-ben alapított négykarú Magyar Királyi Kolozsvári Tudományegyetem (1881től Magyar Királyi Ferenc József Tudományegyetem) meghatározó szerepet töltött be az erdélyi és az Erdéllyel szomszédos régiók kulturális és tudományos fejlődésében, a magyarság kulturális, gazdasági és közéleti fejlődésében, önszerveződésében. Az egyetem épületeit, tudományos gyűjteményeit (könyvtár, levéltár, ásvány és kőzettár, térképtár, fotótár, botanikus gyüjtemény, állattani gyüjtemény) és adminisztrációs iratanyagát 1919. május 12-én a román hadsereggel fellépő megszálló hatóságok vették át. Tisza vonalától északra vagy nyugatra született professzorokat és hallgatókat rövidesen kiutasították. A kiutasított professzorokat - akár saját tulajdonú, akár bérelt lakásokban éltek Kolozsvárt - a határozatnak érvényt szerezve, alig néhány órai csomagolást és mindössze egy-két táskányi holmit engedélyezve - családtagjaikkal együtt ki is toloncolták a román megszállási zónából. Az ilyen módon eltávolított professzorok és hallgatók előbb 1920 tavaszától Budapesten, majd 1921. október 9-től Szegeden folytatták munkájukat. Így a mai Szegedi Tudományegyetem és a kolozsvári Babeş-Bolyai Tudományegyetem ugyanannak a kolozsvári magyar egyetemnek a szellemi és eszmei örökösei. ${ }^{1}$

\footnotetext{
${ }^{1}$ Márki Sándor, A M. Kir. Ferencz József-tudományegyetem története 1872-1922, Szeged, 1922, 149-
} 
A Szegedi Tudományegyetem Levéltára által 2014 tavaszán indított program célja az egyetem 1872-1919 közötti működésével kapcsolatos levéltári és könyvtári dokumentumok feltárása különféle kolozsvári, marosvásárhelyi és magyarországi gyüjteményekből, a dokumentumok digitalizálása, a digitalizált állományoknak elsősorban az egyetemi hallgatók és oktatók számára való közreadása, $s$ a történeti kutatások elősegítése, a témával foglalkozó kutatók közötti szakmai párbeszéd élénkítése. A történeti iratok felkutatása és digitalizálása során létrejövő elektronikus állományokat a Szegedi Tudományegyetem mellett a Babeş-Bolyai Tudományegyetem is megkapja.

A program kétségkívül hasonlóságot mutat az ELTE Történelem Segédtudományai Tanszék szervezésében tucatnyi kiváló szakember ötéves munkájával összeállított tematikus egyetemtörténeti repertóriummal, ${ }^{2}$ amely nemcsak az ELTE egyetemi levéltárának fondjait ismerteti, de a teljesség igényével részletesen felsorolja az egyéb gyüjteményekben (könyvtárak kézirattáraiban, köz- és nyilvános magánlevéltárakban) található egyetemtörténeti dokumentumokat is. Programunk annyiban különbözik a 30 évvel korábbi fóvárosi kutatástól, hogy - kiaknázva a modern műszaki eszközök nyújtotta lehetőségeket - a feltárt irategyüttesekről egyúttal nagy felbontású digitális fotó is készül a részletes egyetemtörténeti kutatások elősegítésére. Így a magyarországi kutatók munkája a továbbiakban csak kivételes esetekben igényel hosszas kolozsvári és marosvásárhelyi helyszíni kutatást.

\section{A program indokoltsága}

A kolozsvári egyetem története napjainkban különösen kiemelt témája a különféle tudományos és közművelődési rendezvényeknek. Ugyanakkor a Magyar Királyi Ferenc József Tudományegyetem 1919. május 12. utáni elűzése során nem volt lehetőség a történeti dokumentumok Magyarországra hozatalára, azokat a kiépülő román impérium magának követelte. Így az iratanyag Kolozsváron 1947-ig az egyetemi irattárban, 1947-1949 között (egészen az egyesület feloszlatásáig) az Erdélyi Múzeum-Egyesület Levéltárában maradt.

158.; vitéz NAGY Iván, A számüzetés évei Szegeden 1920-1940 = Erdély magyar egyeteme. szerk. Bisztray Gyula, Szabó T. Attila, Tamás Lajos, Kolozsvár, 1941, 333-368.; GaAl György, Egyetem a Farkas utcában: A kolozsvári Ferenc József Tudományegyetem elözményei, korszakai és vonzatai, Kolozsvár, 2012, 87-88. Ezt fejezi ki a Szegedi Tudományegyetem és a Babeş-Bolyai Tudományegyetem által aláírt együttműködési szerződés is az egyetemtörténeti kutatásokról és az örökség közös ápolásáról. http://szegedma.hu/hir/szeged/2017/05/egyuttmukodesi-megallapodast-kotott-az-szte-a-babesbolyai-tudomanyegyetemmel.html (letöltve: 2017. május 12.)

${ }^{2}$ Egyetemünk történetének levéltári és kézirattári forrásai 1635-1970, szerk. SzöGI László, (Fejezetek az Eötvös Loránd Tudományegyetem történetéből 8.), Budapest, 1985, I-II. 
MMXVII VOL. VIII. NR. 2

\section{9-ben az Erdélyi Múzeum-Egyesület Levéltárában őrzött egyetemtörténeti iratanyag ${ }^{3}$}

\begin{tabular}{|l|c|c|}
\hline \multicolumn{1}{|c|}{ Fond } & Évkör & Mennyiség \\
\hline Farkas Lajos egyetemi tanár (1873-1915) személyi lt. & & 3 csomó \\
\hline Halász Ignác egyetemi tanár (1893-1901) személyi lt. & $1855-1901$ & \\
\hline Magyar Tudományegyetem Rektori Hivatal & $1872-1918$ & 250 csomó és 30 fm \\
\hline Magyar Tudományegyetem BTK & $1872-1918$ & 100 csomó és $10 \mathrm{fm}$ \\
\hline Magyar Tudományegyetem TTK & $1872-1918$ & 80 csomó és $10 \mathrm{fm}$ \\
\hline Martin Lajos (1827-1897) egyetemi tanár személyi lt. & & 1 csomó \\
\hline Szabó Károly (1824-1890) egyetemi tanár levelezése & & 2272 db (6 dobozban) \\
\hline Vályi Gyula (1855-1913) egyetemi tanár személyi lt. & & 2 csomó \\
\hline
\end{tabular}

Az Erdélyi Múzeum-Egyesület Levéltárából 1949-ben a Román Állami Levéltár Kolozs Megyei Levéltára tulajdonába kerültek át az egyetemtörténeti dokumentumok. Kivéve az Orvostudományi Kar iratait, amelyek 1945-ben a magyar nyelvü orvos- és gyógyszerészképzéssel együtt Marosvásárhelyre, a Marosvásárhelyi Orvosi és Gyógyszerészeti Intézetbe, majd onnan 1971-ben a Román Állami Levéltár Maros Megyei Levéltárának tulajdonába kerültek. ${ }^{4} \mathrm{~A}$ megyei levéltárak által átvett egyetemtörténeti iratok hosszú évtizedeken át a történeti kutatás számára teljességgel elérhetetlenek voltak. ${ }^{5}$ A kutatók munkáját nagyban megnehezítette, hogy a megyei levéltár a Belügyminisztériumhoz tartozva nem a kultúra és a tudomány érdekeit tartotta szem előtt müködése során. A rendőrség és a Securitate (románul: Departamentul Securitătiii Statului, azaz Állambiztonsági Osztály), a román kommunista diktatúra titkosszolgálata szorosan felügyelte és alapjaiban határozta meg e levéltárak működését 1990-ig. Így a megyei levéltárakban lévő egyetemi iratanyag ismeretlennek számít mind a román, mind a magyar történészek előtt, s a kolozsvári egyetemnek 1872-1919 közötti történetét, valamint a város, a szűkebb régió és Erdély társadalmára, művelődési és tudományos, gazdasági fejlődésére gyakorolt hatását a történeti tudomány a mai napig nem tudta korabeli források alapján vizsgálni és feldolgozni. Igen ritka azon kiadványok sora, amely részletes levéltári dokumentumokat közöl, vagy amelyek levéltári dokumentumok szisztematikus feldolgozásával, elemzésével készültek. ${ }^{6}$

${ }^{3}$ Erről tanúskodik: Jakó Zsigmond, Hegyi Géza, W. Kovács András, Az Erdélyi Nemzeti Múzeum Levéltárának fondjegyzéke (1949. évi állapot) = Az Erdélyi Múzeum-Egyesület gyüjteményei, szerk. Sipos Gábor, Kolozsvár, 2009, 223-234.

${ }^{4}$ PÁL-Antal Sándor, Maros megye. (Az 1918/1919 elötti Erdélyre vonatkozó fondok és gyüjtemények jegyzékei 12. kötet.), Budapest-Bukarest, 2014.

5 Erről meggyőzően tanúskodnak a levéltári dobozokban található kutatói jegyzékek, amelyekben 1990 előtti bejegyzés nem található, $s$ a legtöbb doboz vagy kötet esetében 1990 óta is alig 2-4 alkalommal történt kutatás.

${ }^{6}$ Például: Dokumentumok a kolozsvári Bölcsészet-, Nyelv-és Történettudományi Kar történetéhez (18721892), szerk. T. Szabó Levente, Zabán Márta. Kolozsvár, 2012; Pósta Béla, Az Erdélyi Nemzeti Múzeum Érem-és Régiségtárának története. (Erdélyi Tudományos Füzetek 279.), Kolozsvár, 2013; VINCzE Zoltán, A kolozsvári régészeti iskola a Pósta Béla-korszakban (1899-1919), Kolozsvár, 2014. 
A jelenlegi kutatási projekt azzal kecsegtet, hogy végre úgy a kolozsvári, mind a szegedi és általában a magyarországi történettudomány számára elérhetővé válnak a pótolhatatlan értékű irategyüttesek, $s$ az egyetemtörténeti feldolgozások, a különféle kulturális programok (pl. kiállítások, konferenciák, kiadványok) a modern történettudomány elvárásainak megfelelően nagymennyiségű korabeli dokumentum segítségével, forrás centrikus módszer alkalmazásával születhetnek meg.

\section{A program elökészitése és elsö fázisa}

A Szegedi Tudományegyetem Levéltára először 2013. november 8-án szervezett nemzetközi egyetemtörténeti konferenciát a kolozsvári egyetem 1872-1921 közötti történetéről Kolozsvár - Budapest-Szeged. Egyetemünk fél évszázada (1872-1921) címmel. ${ }^{7}$ A konferencia jó alkalmat jelentett a magyarországi és kolozsvári, marosvásárhelyi kutatók közötti személyes kapcsolat kialakítására.

2014 áprilisa és 2017. április 30. között a Szegedi Tudományegyetem Levéltára (különféle pályázati támogatások felhasználásával) 18 gyűjtőutat valósított meg Kolozsváron és Marosvásárhelyen.

\section{A 2014-2016 során felkeresett kolozsvári és marosvásárhelyi gyüjtemények}

\begin{tabular}{|c|c|}
\hline Gyüjtemény & Cím \\
\hline Kolozs Megyei Levéltár ${ }^{8}$ & Cluj-Napoca str. M. Kogălniceanu 10. \\
\hline Maros Megyei Levéltár ${ }^{9}$ & Targu-Mures str. Crizantemelor 8. \\
\hline Babeş-Bolyai Tudományegyetem Levéltára ${ }^{10}$ & Cluj-Napoca str.Teodor Mihail 58-60. \\
\hline Babeş-Bolyai Tudományegyetem Múzeuma ${ }^{11}$ & Cluj-Napoca str. M. Kogălniceanu 4. \\
\hline Lucian Blaga Központi Egyetemi Könyvtár ${ }^{12}$ & Cluj-Napoca str. Clinicilor 2. \\
\hline Erdélyi Unitárius Egyház Gyűjtőlevéltára ${ }^{13}$ & Cluj-Napoca bd. 21 Decembrie 19899. \\
\hline $\begin{array}{l}\text { Erdélyi Református Egyházkerület } \\
\text { Gyüjtőlevéltára }^{14}\end{array}$ & Cluj-Napoca piața Avram Iancu nr. 14-15. \\
\hline Kolozsvári Akadémiai Könyvtár ${ }^{15}$ & Cluj-Napoca str. M. Kogălniceanu 12-14. \\
\hline
\end{tabular}

${ }^{7}$ http://www.u-szeged.hu/sztehirek/2013-november/nagyito-alatt-egyetemunk (letöltve: 2017. február 9.) http://www.u-szeged.hu/sztehirek/2013-november/egyetemtorteneti-131109 (letöltve: 2017. február 9.)

${ }^{8}$ http://www.arhivelenationale.ro/index.php?lan=0\&jud=88 (letöltve: 2017 . február 9.)

${ }^{9}$ http://www.arhivelenationale.ro/index.php?lan=0\&jud=104 (letöltve: 2017. február 9.)

${ }_{10} \mathrm{http} / /$ www.ubbcluj.ro/ro/structura/unitati/directia_patrimoniu_cultural (letöltve: 2017. február 9.)

${ }^{11} \mathrm{http}: / /$ www.ubbcluj.ro/hu/structura/muzee/muzeul_universitatii (letöltve: 2017. február 9.)

12 http://www.bcucluj.ro/hu/ (letöltve: 2017. február 9.)

${ }_{13}$ http://www.melte.hu/?q=node/113 (letöltve: 2017. február 9.)

${ }^{14} \mathrm{http}: / /$ www.reformatus.ro/cimtar.html?ekid=1426 (letöltve: 2017. február 9.)

15 http://www.biblio.acad-cluj.ro (letöltve: 2017. február 9.) 
A levéltár vezetője minden felkeresett gyüjteményben személyes kapcsolatot alakított ki a döntéshozó vezetővel, valamint a könyvtári katalógusok és levéltári segédletek használatában és a dokumentumok kikérésében segédkező, a kutató- vagy olvasótermet felügyelő (részben magyar) levéltári vagy könyvtári alkalmazottakkal, akik számos hasznos tanáccsal és információval segítették a raktári jegyzékek áttekintését, a dokumentumok, valamint a szakirodalom összegyüjtését és a még felkeresendő további gyűjtemények elérését. Sok bátorítást és segítséget kaptunk a kolozsvári egyetemtörténet tapasztalt kutatóitól is (pl. Péter H. Mária, Péter Mihály, Gaal György és Vekov Károly).

A 2014-2016. évi utak során kiépített személyes kapcsolatok

\begin{tabular}{|l|l|l|}
\hline \multicolumn{1}{|c|}{ Intézmény } & \multicolumn{1}{c|}{ Személy } & \multicolumn{1}{c|}{ Beosztás } \\
\hline \multirow{2}{*}{ Kolozs Megyei Levéltár } & Paula Ivan & igazgató \\
\cline { 2 - 3 } & Flóra Ágnes & levéltáros \\
\hline \multirow{2}{*}{ BBTE Egyetemi Múzeum } & Ana-Maria Stan & igazgató \\
\hline \multirow{4}{*}{ Lucian Blaga Központi Egyetemi Könyvtár } & Emilia Cismas & igazgató \\
\cline { 2 - 3 } & Kellmann László & levéltáros \\
\cline { 2 - 3 } & Poráczky Rozália & igazgatóhelyettes \\
\hline \multirow{2}{*}{$\begin{array}{l}\text { Erdélyi Reformi Levéltár } \\
\text { levéltára }\end{array}$} & Kolumbán Mihály Judit & könyvtáros \\
\hline \multirow{2}{*}{ Erdélyi Unitárius Egyháros } \\
\hline \multirow{2}{*}{ Maros Megyei Gyüjtőlevéltára } & Sipos Gábor & igazgató \\
\cline { 2 - 3 } & Ösz Sándor Előd & levéltáros \\
\hline & Molnár B. Lehel & igazgató \\
\hline & Liviu Boar & igazgató \\
\cline { 2 - 3 } & László Márton & levéltáros \\
\hline
\end{tabular}

A Szegedi Tudományegyetem Levéltára a kolozsvári és marosvásárhelyi gyüjtemények mellett személyes kapcsolatot és szoros szakmai együttmüködést alakított ki a Babeş-Bolyai Tudományegyetem több munkatársával, akik érintettek az egyetemtörténeti kutatásokban. Megbeszéléseink eredményeként nem csak személyesen vállalnak szerepet a felkutatott és befényképezett dokumentumok vizsgálatában, elemzésében, de hallgatóikat is a kolozsvári gyüjteményekben őrzött magyar egyetemtörténeti források további feltárására irányítják. Ennek eredményeképpen már meg is indult olyan diplomamunka (szakdolgozat) készítése kolozsvári egyetemista részéről, amely egyszerre egyetem- és várostörténeti téma. 
A Kolozs Megyei Levéltár egyetemtörténeti vonatkozású fondjai ${ }^{16}$

\begin{tabular}{|c|l|c|}
\hline \multicolumn{1}{|c|}{ Fzám } & \multicolumn{1}{|c|}{ Fond } & Évkör \\
\hline 193. & Kolozsvári kereskedelmi akadémia & $1878-1923$ \\
\hline 204. & Kolozsvári katolikus líceum & $1702-1948$ \\
\hline 287. & Központi Egyetemi Könyvtár iratai & $1902-1908$ \\
\hline 315. & FJTE iratai & $1872-1918$ \\
\hline 451. & Vályi-család iratai (pl. Vályi Gábor) & $1629-1977$ \\
\hline 505. & Martin Lajos professzor irathagyatéka & $1871-1913$ \\
\hline 593. & Kelemen Lajos irathagyatéka & $1752-1961$ \\
\hline 799. & Kolozsmonostori gazdasági tanintézet & $1869-1964$ \\
\hline 931. & Szabó Károly irathagyatéka & $1840-1906$ \\
\hline 937. & Hodor Károly irathagyatéka & $1650-1896$ \\
\hline 1188. & Kolozsvári zenekonzervatórium & $1819-1950$ \\
\hline 1363. & Bolyai Tudományegyetem iratai & $1913-1959$ \\
\hline
\end{tabular}

A forrásgyüjtés és digitális fotózás

Első lépésként sikerült feltárni azokat a levéltári fondokat, állományokat és könyvtári gyüjteményeket, amelyekben a kolozsvári egyetem 1872-1919 közötti dokumentumai találhatók. Második lépésként a feltárást követően megkezdett intenzív fotózási programban 2017. április 30-ig mintegy 340 ezer oldalról készült nagy felbontású (5-16 megapixel méretü) digitális fényképet készítettünk, melyek döntő többségét - az elkészült 194463 oldal levéltári fotómásolatból 190234 db, azaz 97,8\% - erdélyi gyüjteményekből tártuk fel.

Legtöbb fotót Kolozsváron a Román Állami Levéltár Kolozs Megyei Levéltárában készítettünk. Itt a 315. számú fondban őrzik a kolozsvári egyetem 1872-1919 közötti iratanyagának legnagyobb részét, nevezetesen a Rektori Hivatal, a Bölcsészet-, Nyelv- és Történettudományi Kar, valamint a Jog- és Államtudományi Kar iktatott iratait (utóbbi kar iratait azonban sajnos - egyelőre - még nem lehet kutatni rendezetlen állapota miatt). A Rektori Hivatal, valamint a Bölcsészet-, Nyelv- és Történettudományi Kar iratai között az iktatott anyagok mellett megtalálhatók az Egyetemi Tanács, valamint a kari tanácsok üléseinek jegyzőkönyvei is. Az iktatott iratokban számos professzori álláspályázat, külföldi tudományos kongresszusokról készített beszámoló, tanszékfejlesztési beadvány, az egyetemi építkezésekkel, a hallgatók vagy a tanárok közéleti és egyesületi tevékenységével, a hallgatók elleni fegyelmi ügyekkel, diákszociális programokkal kapcsolatos irat található. Szintén a 315. számú fondon belül találhatók az egykori iktató-

${ }^{16} \mathrm{http} / / /$ www.arhivelenationale.ro/images/custom/image/Pdf-uri/DJAN-uri/DJAN_CLUJ_fonduri_ si_colectii_date_in_cercetare.pdf (letöltve: 2017. március 21.) 
és mutatókönyvek, valamint a hallgatók különféle nyilvántartásai (a származási ívek, a távozási és végbizonyítványok, a szigorlati és doktori jegyzékek), amelyek alapján a megjelent szociológiai elemzések ${ }^{17}$ alapjául szolgáló teljes dokumentumállomány digitalizálása kezdődhetett meg.

Marosvásárhelyen a Román Állami Levéltár Maros Megyei Levéltárának 576. sz. fondjában találhatók meg a kolozsvári egyetem Orvostudományi Karának iratai a 18. századi Orvos-Sebészeti Tanintézettől kezdve egészen a magyar nyelvü orvos- és gyógyszerészképzés 1945 -ös áthelyezéséig. ${ }^{18}$ Így kutathatók a Kari Tanács üléseinek jegyzőkönyvei, az orvostan- és gyógyszerész-hallgatók törzskönyvei, ${ }^{19}$ szigorlati jegyzőkönyvei, valamint az Orvostudományi Kar iktatott iratai. Összességében megállapítható, hogy a két megyei levéltárban megőrzött és kutatható iratanyag többszörösen felülmúlja a budapesti egyetem ugyanebben az időből fennmaradt dokumentumainak mennyiségét és minőségét. A digitalizált dokumentumok segítségével olyan részletes elemzések végezhetők el a kolozsvári egyetemen, ami egyetlen másik magyar felsőoktatási intézmény esetében sem.

Az egyetem (Kolozs és Maros megyei levéltárakban őrzött) hivatali iratanyagát jól kiegészítik a kolozsvári egyházi levéltárakban őrzött professzori irathagyatékok. Az Erdélyi Református Egyházkerület Gyüjtőlevéltárában e mellett értékes iratok találhatók a Református Theológiai Fakultás és az állami tudományegyetem szakmai kapcsolatairól, a teológiai internátusnak az egyetemisták számára nyújtott szolgáltatásairól, a teológus hallgatóknak az egyetemen folytatott tanulmányairól, valamint a teológiai fakultáson belül 1920/21-ben működtetett Felekezetközi Egyetemről. ${ }^{20}$

${ }^{17}$ NAGY Péter Tibor, A kolozsvári bölcsészkar és természettudományi kar hallgatóságának felekezeti rekrutációja (1872-1918), Magyar Pedagógia, 106 (2006), 5-28; Péter Tibor NAGY, The University of Kolozsvar/Cluj and the Students of the Humanities and Science Faculties (1872-1918), Historical Social Research, 33(2008), 127-153.; Péter Tibor NAGY, Educated elites and the Transsylvanian university (1872-1918) = Tudásjavak áramlása a közép-kelet-európai régióban a rendszerváltást követően: Magyar Szociológiai Társaság éves konferenciája, szerk. Tibori Tímea, LAKI Ildikó, Budapest-Szeged, 2009; KARÁdY Viktor, Kolozsvár mint iskolaváros a Kárpát-medence elitképzési piacán (1872-1918) = 140 éves a kolozsvári magyar nyelvű egyetemi oktatás, szerk. BATIz Enikő, NAGY László, Soós Anna, Kolozsvár, 2013, 237-244.

${ }^{18}$ http://leveltar.adatbank.transindex.ro/?megye=Maros\&kezd=251 (letöltés: 2017. február 19.) és http://www.arhivelenationale.ro/index.php?lan=0\&jud=104 (letöltés: 2017. március 21.)

19 Karády Viktor, A kolozsvári egyetem medikusai a magyar orvosi piacon (1872-1918), Educatio, 11 (2002), 237-252; Victor Karady, Lucian Nastasă, The University of Kolozsvár/Cluj and The Students of The Mediacal Faculty (1872-1918), Budapest-Cluj, 2004. interneten: http://www.edrc.ro/docs/ docs/medical/intregul_volum.pdf (letöltés: 2017. február 19.)

20 A Református Theológiai Fakultáson belül nagyfokú önállósággal működött az 1920/21. tanévben a Felekezetközi Egyetem. ERdÉsz Ádám, A kolozsvári felekezetközi egyetem 1920-1921, Történelmi Szemle 40 (1998), 257-276; Kiss József Mihály, Párhuzamos utak: A kolozsvári és pozsonyi egyetem válságos idöszakának történetéhez = Tanulmányok a magyar felsőoktatás XIX-XX. századi történetéből, szerk. Kıss József Mihály, (Fejezetek az Eötvös Loránd Tudományegyetem történetéből 14.), Budapest, 1991, 123-161; Uő, A kolozsvári „menekült egyetem” 1919. évi történetére vonatkozó dokumentumok Szandtner Pál iratai között, Egyetemi Könyvtár Évkönyvei 10 (2001), 139-160; VINCZE Gábor, 


\section{Az Erdélyi Református Egyházkerület Gyüjtőlevéltárának egyetemtörténeti vonatkozású fondjai}

\begin{tabular}{|c|l|c|c|}
\hline Szám & \multicolumn{1}{|c|}{ Fond tárgya } & Évkör & Mennyiség \\
\hline A 25 & A kolozsvári Református Theológiai Fakultás levéltára ${ }^{21}$ & $1895-1945$ & 3,4 ifm \\
\hline F 6 & Schneller István professzor hagyatéka & $1895-1923$ & 0,55 ifm \\
\hline F 21 & Gyalui Farkas egy. könyvtár ig. helyettese hagyatéka ${ }^{22}$ & $1914-1921$ & 0,02 ifm \\
\hline H 3 & Kolozsvári Ferencz József TE, Természettudományi Kar & $1875-1909$ & 0,05 ifm \\
\hline
\end{tabular}

2017 áprilisában kezdődött meg a Kolozsvári Akadémiai Könyvtárban őrzött 1872-1919 közötti kolozsvári egyetemi órai jegyzetek fotózása. A könyvtár kéziratainak kutatásához különféle korábbi nyomtatott, ${ }^{23}$ illetve a helyszínen használható cédulakatalógusok kerültek felhasználásra. Az órai jegyzetek segítségével részletesen tanulmányozható az oktatott tananyag, valamint a tanítás módszertana is.

Az erdélyi gyűjtemények mellett jelentős eredmények születtek a különféle magyarországi gyűjtemények kolozsvári egyetemtörténeti vonatkozású anyagainak feltárásában és összegyüjtésében is. A Magyar Tudományos Akadémia Könyvtár és Információs Központ Kézirattárának online katalógusa segítségével egykori professzorok vagy híres közéleti, tudományos személyiséggé vált egyetemi hallgatók levelezése, kinevezési okmányaik, egyetemi órai jegyzetek igen nagymennyiségben tárhatók fel. ${ }^{24} \mathrm{Az}$ Országos Széchényi Könyvtár Kézirattárában őrzött egyetemtörténeti dokumentumok kigyüjtését megkönnyítette az Arcanum Adatbázis Kft. által kiadott CD-ROM-ok. ${ }^{25}$ Így a volt egyetemi tanároknak vagy hozzájuk írt több száz levél, értékes napló ${ }^{26}$ és egyetemi előadások órai jegyzetei ${ }^{27}$ kerültek a kutatás homlokterébe. Szintén jelentős profeszszori hagyatékok találhatók a Magyar Természettudományi Múzeum Tudománytör-

A kolozsvári Ferenc József Tudományegyetem felszámolása 1919-ben, Pro Minoritate 14 (2004/2-3), 130-155; Uỏ, A bujdosó egyetem Szegedre kerülése, Valóság 49 (2006/4), 26-55; Uő, A számüzött egyetem: A Ferenc József Tudományegyetem sorsa Kolozsvártól Szegedig (1919-1921), Szeged, 2006, 73-88.

${ }^{21}$ Nagy Géza, A Kolozsvári Református Theológiai Fakultás története, Kolozsvár, 1995, 143.

22 Gyalui Farkas, Emlékirataim 1914-1921, Sajtó alá rendezte, a jegyzeteket és az előszór írta Sas Péter, Kolozsvár, 2013.

${ }^{23}$ BenczéDi Pál, $A$ volt kolozsvári Unitárius Kollégium könyvtárának kézirattáráról = Emlékkönyv Kelemen Lajos születésének 80. évfordulójára, szerk. Bodor András, Bukarest-Kolozsvár, 1957, 33-45; LAKó Elemér, A Kolozsvári Unitárius Kollégium Könyvtárának kéziratai a kolozsvári akadémiai könyvtárban = Mủvelődéstörténeti Tanulmányok, szerk. Csetri Elek, JAKó Zsigmond, Sipos Gábor, TonK Sándor, Bukarest, 1980, 201-220; Uö, The Manuscripts of Unitarian College of Cluj/Kolozsvár int he Library of the Academy in Cluj-Napoca, Szeged, 1997.

${ }^{24}$ http://konyvtar.mta.hu/ (letöltés: 2017. február 19.) A kolozsvári egyetem professzorai közül eddig mindössze a Márki Sándorhoz írt 9088 levélről jelent meg nyomtatásban segédlet: KovácH Géza, Márki Sándor emlékezete és hagyatéka, (EMKE-füzetek V.), Arad, 2000, 47-71.

25 Országos Széchényi Könyvtár Magyar vonatkozású kéziratkatalógusok tára I-II, CD-ROM, Budapest, [é. n.]

${ }^{26}$ Például Somló Bódog naplójegyzetei (1914-1918), OSZK Kézirattár Quart. Hung. 3038.

27 Például Endes Miklós, Jegyzetek és gépiratok I-III., OSZK Kézirattár Quart. Hung. 2886. 
téneti Gyüjteményében (pl. Apáthy István, Borbás Vince, Cholnoky Jenő, Győrffy István, Istvánffi Gyula, Kanitz Ágoston, Koch Antal, Richter Aladár, Rigler Gusztáv, Szádeczky Gyula). ${ }^{28}$ A budapesti gyüjtemények közös tulajdonsága, hogy az értékes dokumentumok fotózását nem engedélyezik. A feltárt iratok szövegét vagy a helyszínen kell begépelni, vagy a gyüjtemény által kínált, igencsak költséges digitalizálással lehet másolatot készíttetni.

A fóvárosi gyüjtemények mellett vidéken is sikerült egyetemtörténeti dokumentumokat gyűjteni. Érden a Magyar Földrajzi Múzeumban Cholnoky Jenőnek, a kolozsvári földrajzi tanszék 1905-1919 közötti vezetőjének gazdag hagyatékában található páratlanul becses terepi naplóinak harminc kötete, valamint igen értékes levelek, órai jegyzetek, sajtóválogatás, fényképgyüjtemény, hallgatók által hozzá készített házi dolgozatok. ${ }^{29}$ A Pannonhalmi Főapátsági Könyvtár kéziratai között található Erdélyi László professzor gazdag hagyatéka. Gyulán a Magyar Nemzeti Levéltár Békés Megyei Levéltárában a Xerox Tár 251. tétele Márki Sándornak, a kolozsvári egyetem történelemprofesszorának 1873 és 1825 között vezetett, mintegy 6000 oldal terjedelmü naplóinak fénymásolatát foglalja magában. A páratlan értékủ dokumentum felhasználásával már készültek résztanulmányok, ${ }^{30} \mathrm{~s}$ a közelmúltban megindult ugyan a napló szövegének kiadása is ${ }^{31}$ a kolozsvári-szegedi egyetemtörténeti kutatások elősegítése érdekében azonban elkészítettük az 1914-1918 közötti 5 esztendő 700 oldalának fotómásolatát is.

\section{A 2014-2016 között elkészült levéltári fotómásolatok megoszlása az őrzőhelyek szerint}

(dőlt betűvel jelölve az erdélyi gyűjtemények anyaga)

\begin{tabular}{|l|c|}
\hline \multicolumn{1}{|c|}{ Iratőrző intézmény } & Oldalszám \\
\hline Kolozs Megyei Levéltár & 141527 \\
\hline Erdélyi Ref. Egyházkerület Levéltára & 2500 \\
\hline Unitárius Levéltár & 107 \\
\hline Román Akadémia Kolozsvári Könyvtára & 1100 \\
\hline Maros Megyei Levéltár & 45000 \\
\hline
\end{tabular}

${ }^{28}$ www.nhmus.hu/hu/konyvtar/tudomanytorteneti_gyujtemeny (letöltés: 2017. február 19.)

${ }^{29}$ www.foldrajzimuzeum.hu (letöltés: 2017. február 19.)

${ }^{30}$ ERDÉsz Ádám, Félelem és remény az összeomlás árnyékában. Márki Sándor kolozsvári naplóiból = Régi témák, mai kérdések a mentalitás-történetben. (Rendi társadalom - polgári társadalom 11.), szerk. Sasfi Csaba, Esztergom, 2000, 124-134; Gyarmati Zsolt, Polgári otthon a Márki-napló tükrében (1892-1902) = Uő, Nyilvánosság és magánélet a békeidők Kolozsvárán, Kolozsvár, 2005, 192-230; Uö, A Mátyás-szobor elötörténete szubjektív megközelitésben = Uö, Nyilvánosság és magánélet a békeidők Kolozsvárán, Kolozsvár, 2005, 231-247. ERDÉsz Ádám, Katedra, társadalom, magánélet: Márki Sándor kolozsvári mindennapjai = Ünnepi kötet Dr. Blazovich László egyetemi tanár 70. születésnapjára. (Acta Universitatis Szegediensis. Acta Juridica et Politica Tom. LXXV.) Szeged, 2013, 185-197.

${ }^{31}$ Márki Sándor naplói (1873-1925), I. kötet (1873-1892), szerk. Erdész Ádám. Gyula, 2015. 


\begin{tabular}{|l|c|}
\hline \multicolumn{1}{|c|}{ Iratőrző intézmény } & Oldalszám \\
\hline MTA Könyvtár Kézirattár & 405 \\
\hline OSZK Kézirattár & 220 \\
\hline Természettudományi Múzeum & 240 \\
\hline Magyar Földrajzi Múzeum & 1454 \\
\hline Pannonhalmi Könyvtár & 205 \\
\hline Békés Megyei Levéltár & 705 \\
\hline Összesen & $\mathbf{1 9 4 4 6 3}$ \\
\hline
\end{tabular}

A felsorolt levéltári dokumentumok mellett, az egyetem hivatali iratanyagának kiegészítésére a kolozsvári Lucian Blaga Központi Egyetemi Könyvtárban őrzött, igen értékes 1872-1919 közötti kolozsvári hírlapi anyag feltárása és fotózása ügyében is jelentős eredmények születtek. Kiindulásként figyelembe kell venni, hogy a Szegedi Tudományegyetem Klebelsberg Könyvtára - a Kolozsvárról 1919 májusában történő elüzés következtében - sajnos igen szerény kolozsvári hírlapi állománnyal rendelkezik. Mindössze a Kolozsvári Egyetemi Lapok (1897-98) az Új Egyetem (1910-11) c. lapok 1-2. évfolyama, Az Egyetem (1903) és az Egyetem (1909/10) címü lapok egy-egy évfolyama került be a gyüjteménybe professzori magánkönyvtárak felvásárlása folytán. ${ }^{32}$ Első lépésként különféle sajtótörténeti feldolgozások, ${ }^{33}$ valamint nyomtatott és online könyvtári katalógusok segítségével összegyüjtöttük az 1872-1919 közötti kolozsvári kiadású napi- és hetilapok címeit, valamint az egyes sajtótermékek megjelenési időszakait. A lapok döntő többségéhez Kolozsváron a Lucian Blaga Központi Egyetemi Könyvtárban jutottunk hozzá. Ugyanakkor a munka meggyorsítása érdekében az Erdélyi Gazda és a kolozsmonostori M. Kir. Gazdasági Tanintézet (1904-től kolozsvári, 1906-tól pedig Gazdasági Akadémia) évkönyveit Gödöllőn, a Szent István Egyetem Kosáry Domokos Könyvtár és Levéltár állományából fotóztam be.

\section{A 2014-2016 között elkészült könyvtári fotómásolatok megoszlása az őrzőhelyek szerint}

\begin{tabular}{|l|c|c|}
\hline \multicolumn{1}{|c|}{ Kolozsvári periodikák } & Évkör & Oldalszám \\
\hline Egyetemi Lapok & $1894-1918$ & 4000 \\
\hline Kolozsvári Egyetemi Lapok & 1901 & 380 \\
\hline Ellenzék & $1880-1921$ & 27101 \\
\hline
\end{tabular}

32 A felsorolt diáklapok állományait a könyvtár munkatársai digitalizálták, és egyetemi IP-címről szabadon elérhetővé tették. http://opac2.bibl.u-szeged.hu/szteda/univ (letöltve: 2017. február 12.)

33 KRISTóf György, Az erdélyi idöszaki sajtó a kiegyezéstöl 1867-1919, Magyar Könyvszemle 62 (1938), 41-66; Kozma Dezső, A valóság igézete: Irók kolozsvári szerkesztöségekben a századfordulón, Kolozsvár, 1972, 40-51; FleIsz János, Az erdélyi magyar sajtó története (1890-1940), Pécs, 2005, 55-66, 171-185. 


\begin{tabular}{|l|c|c|}
\hline \multicolumn{1}{|c|}{ Kolozsvári periodikák } & Évkör & Oldalszám \\
\hline Elöre & $1906-1907$ & 1791 \\
\hline Erdélyi Friss Ujság & $1900-1901$ & 2003 \\
\hline Erdélyi Hírlap & $1906-1907$ & 2154 \\
\hline Kelet & 1873,1877 & 1860 \\
\hline Kolozsvár & $1872-1894$ & 18600 \\
\hline Kolozsvári Friss Ujság & 1902 & 407 \\
\hline Kolozsvári Hírlap & $1904-1907$ & 4177 \\
\hline Kolozsvári Közlöny & $1872-1876$ & 5600 \\
\hline Magyar Polgár & $1872-1904$ & 24909 \\
\hline Ujság & $1904-1918$ & 16844 \\
\hline Erdélyi Gazdasági Egylet Egy Éve & $1895-1916$ & 2800 \\
\hline Ungaria ${ }^{34}$ & 1907 & 21970 \\
\hline Erdélyi Gazda & $1869-1918$ & 2005 \\
\hline Kolozsmonostori Akadémia Évkönyve & $1878-1912$ & 136782 \\
\hline Összesen & & \\
\hline
\end{tabular}

\section{A program munkaerö-szükségletének biztositása}

A Szegedi Tudományegyetem Levéltára 2012 ősze óta mindössze egyetlen foállású alkalmazottal rendelkezik, így a fenti program többszörösen meghaladja az egyéb hivatali teendőkkel is alaposan leterhelt munkaerő kapacitását. Az első gyűjtőutakon a Szegedi Tudományegyetem Klebelsberg Könyvtár Egyetemi Gyűjteménye képviseletében Gausz Ildikó fókönyvtáros is aktív szerepet töltött be a dokumentumok válogatásában és fényképezésében. Munkája nem korlátozódott a dokumentumok összegyűjtésére és a digitális fotózásra, a fényképek felhasználásával készülő kiállítások összeállításából is aktívan kivette szerepét. A kolozsvári és marosvásárhelyi gyűjtőutakon többen is segítséget nyújtottak: a Budapesti Corvinus Egyetem Entz Ferenc Könyvtár és Levéltár képviseletében Osváth Zsolt levéltárvezető, a Magyar Képzőművészeti Egyetem Levéltára képviseletében Mátyás Zoltán levéltáros. Kiegészítette a munkát a 2016. áprilisi gyűjtőút során dr. Laczkó Sándor, a Szegedi Tudományegyetem Klebelsberg Könyvtár Különgyűjteményi Osztályának vezetője. 2015 ősze óta pedig több gyűjtőúton aktívan közreműködött dr. Ádám Ildikó jogtörténeti doktorandusz is.

${ }^{34}$ Az Ungaria c. folyóirat bemutatása: Köpeczi Béla, Moldován Gergely a lapszerkesztő = Kisebbségkutatás 10 (2001/1), 85-94. http://epa.oszk.hu/00400/00462/00009/10.htm (letöltve: 2017. február 23.) Az Ungaria 1891-1897 közötti évfolyamait a Lucian Blaga Központi Egyetemi Könyvtár már digitalizálta, így az online szabadon elérhető: dspace.bcucluj.ro/handle/123456789/51756 (letöltve: 2017. február 9.) 
Az egyetemi alkalmazottak mellett meghatározó szerepet töltenek be a program végrehajtásában a levéltár által 2015 tavasza óta az egyetemi Karrier Iroda segítségével meghirdetésre kerülő alternatív gyakornoki programban levéltári munkára jelentkező hallgatók. Szemeszterenként átlagosan 5-6 (többségében történelem szakos) hallgató végez önkéntes gyakornoki munkát a levéltárban, $s$ mellettük alkalmanként további hallgatók is segítenek. A gyakornokok az erdélyi gyűjtőutakon a dokumentumok fotózásában vagy Szegeden az elkészült fotók utómunkálataiban segédkeznek. Ezzel a módszerrel eddig húsznál több egyetemista ismerkedhetett meg a levéltári kutatás és másolatkészítés praktikus fogásaival, $s$ járult hozzá az egyetemi levéltár nagyarányú állománygyarapításához.

\section{A program anyagi fedezete}

A megkezdett dokumentumgyűjtő program többszörösen meghaladja a Szegedi Tudományegyetem Levéltárának a fenntartó által biztosított igen szerény mértékủ teljes költségvetését (összesen 5,6 millió $\mathrm{Ft}$ ). A levéltár költségvetése csak a technikai eszközök (digitális fényképezőgép és tartozékai, mobil tárhely) beszerzését, valamint 3 rövidebb út költségeit biztosította. A külföldi utazások és szállások, a napi fotójegyek költségeinek döntő többsége különféle pályázatok segítségével vált fedezhetővé. 2013ban a Nemzeti Kulturális Alap Közgyüjtemények Kollégiuma nyújtott 530 ezer Ft támogatást Hungarica-kutatásra, valamint 130 ezer Ft-ot az Ithaka-programban marosvásárhelyi iratok Szegedre szállítására. A marosvásárhelyi út kétnapos levéltári fotózásra is lehetőséget nyújtott. 2014-ben a Magyar Levéltárosok Egyesülete engedett át 120 ezer Ft-ot a nemzetközi levéltári kapcsolatok építésére elnyert pályázatából kolozsvári tanulmányútra, amely kiváló alkalmat jelentett levéltári és könyvtári fotózásra is. 2016ban pedig a Magyar Nemzeti Bank Pallas Athéné Domus Concordiae Alapítvány ítélt meg összesen 10 millió Ft támogatást a Magyar Felsőoktatási Levéltári Szövetségnek kolozsvári és szegedi egyetemtörténeti program megvalósítására. Utóbbi támogatásból mintegy 1,84 millió Ft jutott kolozsvári levéltári és könyvtári kutatásra, ebből 4-4 fövel 8, egyenként 4-5 napos gyüjtőutat valósítottunk meg. Szintén 2016-ban nyertem egyhónapos kolozsvári kutatásra Klebelsberg-ösztöndíjat a Balassi Intézettől. Így az ismertetett fotózási program a 2014-2015. évi kezdetek után 2016-ban gyorsulhatott fel igazán.

\section{A digitális másolatok felhasználása}

A program keretében elkészült digitális másolatok felhasználása nagyban megkönnyíti a 2021-re megjelentetni tervezett egyetemtörténeti monográfia munkálatait. A fotókat ugyanis elsőként (2021-ig kizárólag) a felkért szerzők használhatják. 2021 után azonban a széles nagyközönség számára szabadon kutathatók lesznek a másolatok. Ennek 
megkönnyítését szolgálja, hogy a Babeş-Bolyai Tudományegyetem is megkapta (és a továbbiakban is megkapja) az elkészült fotók egy-egy példányát. A fóvárosi kutatók dolgának megkönnyítése érdekében 2017 végén a Magyar Nemzeti Levéltár Országos Levéltára is kap a levéltári irategyüttesekről készített felvételekből.

A gyüjtőprogrammal párhuzamosan mind a Szegedi Tudományegyetemen, mind a Babeş-Bolyai Tudományegyetemen egyetemtörténeti kurzusok indultak a hallgatók számára. A 2015/16. tanév tavaszi és a 2016/17. tanév őszi szemeszterében 2-2 egyetemi kurzus került meghirdetésre és megtartásra a Szegedi Tudományegyetemen és a Babeş-Bolyai Tudományegyetemen is. Mindkét félévben mindkét egyetemen egy elöadás és egy forrásfeldolgozó szeminárium műfajú kurzust tartottak a projektben részt vevő oktatók. 2016 tavaszán A kolozsvári tudományegyetem társadalmi, gazdasági hatása Erdélyben c. elöadás, valamint a Gazdasági ismeretek oktatása a kolozsvári egyetemen (1872-1919) c. szeminárium; a 2016. őszi félévben pedig a Kolozsvár felsöoktatása a dualizmus korában c. elöadás, valamint az Egyetemtörténeti dokumentumok a dualizmus korából c. forrásfeldolgozó szeminárium került megtartásra. A 8 kurzuson együttesen 150 hallgató ismerhette meg a dualizmuskori Magyarország egyik legjelentősebb egyetemének, a kolozsvárinak 1872-1919 közötti történetét. A hallgatók a kurzusokon megismerkedhettek az akkori oktatáspolitika főbb eredményeivel, az egyetem kiépítésének beruházásaival, az egyetem professzorainak tudományos és közéleti munkásságával, az egyetemi hallgatók önképző és segélyegyleteivel, illetve a hallgatókat segítő diákszociális alapítványokkal. A kurzusok során különösen sikeresnek bizonyult a vendégoktatók bevonása, vagyis Szegeden a kolozsvári, Kolozsváron a szegedi oktató által tartott órák igen jól színesítették a kurzusokat. A hallgatók érthető módon igen nagy figyelemmel követték a vendégelőadók által tartott órákat.

\section{A dokumentumgyüjtö és digitalizálási program eredményeinek közzététele}

Munkánkról időközben az SZTE Magazin című szegedi sajtó is beszámolt. ${ }^{35} \mathrm{E}$ mellett a gyüjtőmunka eredményei konferenciákon is ismertetésre kerültek. Például A neveléstörténet kutatása és oktatása a Dél-Alföldön III. A neveléstörténet mint tudományterület változó társadalmi és technikai környezetben c. konferencián az Új források és lehetöségek az egyetemtörténeti kutatásokban c. előadásban; ${ }^{36}$ a Fiatal Levéltárosok Egyesülete VIII. Tudományos nyári táborán (Badacsonytomaj, 2016. augusztus 4.).;7 a Magyar Felsőoktatási Levéltári Szövetség vándorgyűlésén (Debrecen, 2016. szeptember 19-20.) tartott két előadásban. ${ }^{38}$

35 http://www.u-szeged.hu/sztemagazin/tallozo/keszul-masodik?objectParentFolderId=25254 (letöltve: 2017. február 9.)

${ }^{36}$ https://www.facebook.com/events/750756881691082/ (letöltve: 2017. február 9.)

$37 \mathrm{http}: / /$ www.filee.hu/index.php?option=com_content\&view=article\&id=118:beszamolo-a-viiitudomanyos-nyari-taborrol\&catid=36:beszamolo\&Itemid=69 (letöltve: 2017. február 9.)

${ }^{38} \mathrm{http} / /$ archivportal.hu/hu/blog/debrecenben-tartjak-vandorgyulesuket-az-egyetemi-leveltarosok/ (letöltve: 2017. február 9.) 
A gyűjtőutakon befényképezett dokumentumok közül számos, a Szegedi Tudományegyetem Levéltára, valamint az Szegedi Tudományegyetem Klebelsberg Könyvtár Egyetemi Gyűjteménye együttműködésében megvalósuló egyetemtörténeti kiállításokon is bemutatásra kerültek már. Például a Kolozsvári egyetem háborús hétköznapjai (1914-1918) c. kiállításon (2014. november 14.); ${ }^{39}$ az Évfordulós professzori Pantheon - Márki Sándor (1853-1925) c. kiállításon (2015. március 24.);0 az Évfordulós profeszszori Pantheon - Cholnoky Jenö (1870-1950) c. kiállításon (2015. november 3.); ${ }^{41}$ az Elsodort intézetek - A kolozsvári és a szegedi Régészeti Intézet elsö ötven éve (1899-1949) c. kiállításon (2016. április 13.). ${ }^{42}$ 2017. május 12-én valósult meg az „Esz és sziv” A kolozsvári egyetem megalapitása és kiépitése (1872-1919) c. egyetemtörténeti kiállításunk sajtóbemutatója . ${ }^{43}$

A Szegedi Tudományegyetem Egyetemtörténeti Bizottsága és a Babeş-Bolyai Tudományegyetem Egyetemtörténeti Bizottsága két alkalommal tartott részletes megbeszélést az 1872-1919 közötti korszakot célzó egyetemtörténeti kutatások, közös kiállítások, konferenciák, kiadványok, valamint kölcsönös átoktatások összehangolása érdekében. Jelen program jól illeszkedik a két egyetem között megélénkülő közös egyetemtörténeti kutatásokba. A kutatási projekt a szűkebb értelemben vett egyetemtörténet mellett azokat a kapcsolódási pontokat és kisugárzási lehetőségeket öleli fel, amelyek az átlagos intézmény- és oktatástörténeti kiadványokból rendre kimaradnak.

\section{További tennivalóink}

A megkezdett digitalizálási programot újabb pályázati támogatások segítségével folytatni kell, hogy a feltárt levéltári és kézirattári gyűjteményekről minél teljesebb arányban készüljön - részben állományvédelem, részben pedig a kutatás megkönnyítése céljából - digitális másolat. Minden eddig felkeresett gyűjteményben nagymennyiségű további irategyüttesről kell még fotómásolatot készíteni, amire az egyetemtörténettel kapcsolatos valamennyi fond és állag könnyűszerrel kutatható lesz az érdeklődők számára. Mind a kolozsvári, a marosvásárhelyi, mind pedig a budapesti és hazai vidéki gyüjteményekben több százezer oldalnyi dokumentum vár még digitális fotózásra. A kolozsvári és marosvásárhelyi levéltárban az egyetemisták törzskönyvei közül az 1904-1919 közötti, igazán nagy hallgatói létszámú évek, valamint a Jog- és Államtudományi Kar teljes

${ }^{39}$ http://www.u-szeged.hu/sztehirek/2014-november/egyetemtorteneti-141116 (letöltve: 2017. február 9.)

${ }^{40}$ http://www.u-szeged.hu/kongresszusikozpont/kongresszusi-kozpont-150323/marki-sandor-kiallitas (letöltve: 2017. február 9.)

${ }^{41} \mathrm{http}$ ://www.u-szeged.hu/kongresszusikozpont/kongresszusi-kozpont-151102/cholnoki-jenoprofesszor (letöltve: 2017. február 9.)

42 http://www.szegedma.hu/hir/szeged/2016/04/regeszeti-erdekessegek-a-tik-ben-fotok.html (letöltve: 2017. február 9.)

${ }^{43} \mathrm{http} / /$ szegedma.hu/hir/szeged/2017/05/egyuttmukodesi-megallapodast-kotott-az-szte-a-babesbolyai-tudomanyegyetemmel.html (letöltve: 2017. május 12.) 
iratanyaga, a Lucian Blaga Központi Egyetemi Könyvtárban számos hírlapi anyag vár még fotózásra. Az MTA Könyvtár Kézirattárában és az OSZK Kézirattárában egykori professzori levelek ezreiről és igen értékes egyetemi órai jegyzetekről kell még digitális másolatokat készíttetnünk.

Az OSZK Kézirattár kolozsvári egyetemmel kapcsolatos irategyüttesei

\begin{tabular}{|l|l|c|}
\hline \multicolumn{1}{|c|}{ Jelzet } & \multicolumn{1}{c|}{ Téma } & Évkör \\
\hline Fol. Hung. 1673 & Apáthy István politikai levelezése & 20. század eleje \\
\hline Quart. Hung. 2452-2457 & Apáthy István levelezése, iratai & $1890-1922$ \\
\hline Quart. Hung. 2619 & $\begin{array}{l}\text { Márki Sándor: Orosz-magyar szövetség } \\
\text { 1707-ben. }\end{array}$ & 1903 \\
\hline Quart. Hung. 2629-2632 & Meltz Hugó különböző iratai & 19. század vége \\
\hline Quart. Hung. 2707 & $\begin{array}{l}\text { Meltzl Hugó bejegyzései az Összehasonlító } \\
\text { Irodalomtörténeti Lapok c. többnyelvü } \\
\text { folyóirat számaiban }\end{array}$ & $1877-1887$ \\
\hline Quart. Hung. 2886 & $\begin{array}{l}\text { Endes Miklós: egyetemi jegyzetek } \\
\text { és kéziratok I-III. }\end{array}$ & $1890-1894$ \\
\hline Quart. Hung. 2895 & $\begin{array}{l}\text { Csengeri János: Bevezetés } \\
\text { a müvészettörténetbe. Egyetemi órai jegyzet }\end{array}$ & $1906 / 07$ \\
\hline Quart. Hung. 3038-3040 & $\begin{array}{l}\text { Somló Bódog: Naplójegyzetek I-III. } \\
\text { Egyetemi órai jegyzetek }\end{array}$ & $1896-8,1914-9$ \\
\hline Quart. Hung. 3139 & $\begin{array}{l}\text { Csengeri János: Magyar mondattan. } \\
\text { Egyetemi órai jegyzet }\end{array}$ & $1905 / 06$ \\
\hline Quart. Hung. 3153 & $\begin{array}{l}\text { Márki Sándor: Az újkor II. felének rendszeres } \\
\text { történelme. Egyetemi órai jegyzet }\end{array}$ & $1908 / 09$ \\
\hline Quart. Hung. 4112-4115 & $\begin{array}{l}\text { Márki Sándor: Különféle egyetemi órai } \\
\text { jegyzetek }\end{array}$ & $1901-1907$ \\
\hline
\end{tabular}

A már ismert gyűjtemények mellett további hazai és külföldi gyűjteményeket kell felkeresnünk (pl. Piarista Rend Magyar Tartománya Központi Levéltárában a Kolozsvári Kalazantinum iratai, Vajda Gyula, Karl János és Biró Vencel hagyatéka; ${ }^{44}$ ELTE Egyetemi Levéltárban Szandtner Pál iratai, ${ }^{45}$ Semmelweis Egyetem Központi Levéltárában Genersich Antal hagyatéka. ${ }^{46}$ Ezek segédleteinek átkutatása és a vonatkozó iratok

${ }^{44}$ archivum.piar.hu (letöltve: 20147. február 24.)

45 https://leveltar.elte.hu/index.php?option=com_content\&task=view\&id=48\&Itemid=74 (letöltve: 2017. május 12.)

${ }^{46} \mathrm{http} / /$ semmelweis.hu/leveltar/files/2014/03/Fondesallagjegyzek_2015.pdf (letöltve: 2017. május 12.) 
helyszíni fotózása szükséges ahhoz, hogy minél teljesebben rekonstruálhatóvá váljon a kolozsvári egyetem hivatali iratanyagát kiegészítő személyes levelezések, egyetemi órai jegyzetek gyűjteménye. Így például Nagyváradon a Román Állami Levéltár Bihar Megyei Levéltárának 47. számú fondjában 9 doboz irat található a Kolozsvári Tudományegyetem Jog- és Államtudományi Karának dokumentumai közül. ${ }^{47}$ De Magyarországon is számos további egyházi vagy egyetemi gyüjteményt kell még felkeresnünk.

Az elkészült fotókat a levéltári őrzési egységek szerint mappákba rendezve, a szükséges digitális utómunkákat követően lehet csak a kutatók rendelkezésére bocsátani. Ezen a téren még több tízezer fotó forgatása, körbevágása, utólagos képkorrekciók elvégzése van még hátra. Utána azonban a magyar kultúr-, oktatás- és tudománytörténet szempontjából páratlan jelentőségű nagymennyiségü digitalizált dokumentum hosszú évekig az egyetemtörténeti kutatás számára jól hasznosítható kiindulási anyagot nyújt úgy a tudományos kutatás (pl. további forráskiadványok összeállítása), mint az egyetemvagy tudománytörténeti oktatás, valamint a közművelődési és marketing szempontból is jelentős egyetemtörténeti kiállítások számára.

${ }^{47}$ http://leveltar.adatbank.transindex.ro/?megye=Bihar\&kezd=601 (letöltve: 2017 . május 12.) 